\title{
Professor Faustino Esposel: Neurology, football and spiritualism
}

\author{
Professor Faustino Esposel: Neurologia, futebol e espiritismo \\ Luiz Eduardo NOVIS', Péricles Andrade MARANHÃO FILHO², Maria Elisa Paiva PIRES², Mariana SPITZ³,
}

Hélio Afonso Ghizoni TEIVE⿱

\begin{abstract}
Faustino Monteiro Esposel was a renowned neurologist from Rio de Janeiro, born on October 24, 1888. Together with his mentor, Professor Antônio Austregésilo Rodrigues Lima - the founder of modern Brazilian Neurology -, Professor Esposel described one of the rival signs of the Babinski sign, known as the Austregésilo-Esposel sign, in a study published in the renowned journal L'Encéphale in 1912. This article aims to summarize the life story of this illustrious neurologist as well as to highlight his achievements "beyond medicine".
\end{abstract}

Keywords: History of Neurology, Neurology, Semiology, Babinski sign, Austregésilo-Esposel sign.

RESUMO

Faustino Monteiro Esposel foi um renomado neurologista do Rio de Janeiro, nascido em 24 de outubro de 1888. Junto de seu mentor, o Professor Antônio Austregésilo Rodrigues Lima, considerado o pai da Neurologia brasileira moderna, descreveu um dos sinais sucedâneos do sinal de Babinski, conhecido como sinal de Austregésilo-Esposel, publicado no renomado periódico L’Encéphale em 1912. Este artigo tem como objetivo trazer a história deste ilustre neurologista, destacando também seus feitos "além da medicina".

Palavras-chave: História da Neurologia, Neurologia, Semiologia, sinal de Babinski, sinal de Austregésilo-Esposel.

\section{INTRODUCTION}

Neurology in Brazil was deeply influenced by the French school of neurology and its outstanding Neurology Service at the Hospital de la Salpêtrière, in Paris, which was considered the birthplace of Neurology worldwide at the end of the 19th century, with its most prominent figure, Professor JeanMartin Charcot ${ }^{1,2,3,4}$. In Brazil, the first neurology school was founded in 1912, having Professor Antonio Austregésilo as the first professor of the Chair of Neurology at the Faculty of Medicine of Rio de Janeiro, current Federal University of Rio de Janeiro ${ }^{1,2,3,5,6}$. Professor Austregésilo has made several study trips to Europe, mainly to France, for internship programs in neurology services under the supervision of Pierre Marie, Babinski and Dejérine, among others ${ }^{1,2,3,5,6}$.

The School of Neurology directed by Professor Austregésilo, who is considered the founder of modern Brazilian Neurology, has become a reference throughout Brazil. Professor Austregésilo had several disciples, including Professor Deolindo Couto, his successor, and also Professor Esposel $^{1,23,5,6}$. Professor Esposel has worked very close to his master and friend, Professor Austregésilo, with whom he shared the publication of several scientific articles. In addition, he had also replaced his master as chairman of Neurology, when Professor Austregésilo was elected Congressman ${ }^{1,2,3,5,6,7}$. This article aims to point out Professor Esposel's major

${ }^{1}$ Universidade Federal do Paraná, Hospital de Clínicas, Departamento de Medicina Interna, Programa de Pós-Graduação em Medicina Interna, Curitiba PR, Brazil.

${ }^{2}$ Universidade Federal do Rio de Janeiro, Hospital Universitário Clementino Fraga Filho, Departamento de Neurologia, Rio de Janeiro RJ, Brazil.

${ }^{3}$ Universidade Estadual do Rio de Janeiro, Hospital Universitário Pedro Ernesto, Departamento de Neurologia, Rio de Janeiro RJ, Brazil.

${ }^{4}$ Universidade Federal do Paraná, Hospital de Clínicas, Departamento de Medicina Interna, Serviço de Neurologia, Curitiba PR, Brazil.

Luiz Eduardo Novis (D) https://orcid.org/0000-0003-1479-2953; Péricles Andrade Maranhão Filho (D) https://orcid.org/0000-0003-2030-547X; Maria Elisa Paiva Pires (D) https://orcid.org/0000-0001-6990-7434; Mariana Spitz (D) https://orcid.org/0000-0001-7548-2313; Hélio Afonso Ghizoni Teive (D) https://orcid. org/0000-0003-2305-1073

Correspondence: Luiz Eduardo Novis; Email: luizeduardonovis@hotmail.com

Conflict of interest: There is no conflict of interest to declare.

Authors' contributions: LEN: writing, review of the literature, editing; PAMF: resources and review; MEPP: resources; MS: review; HAGT: conceptualization, review and editing, supervision.

Received on January 19, 2021; Received in its final form on February 15, 2021; Accepted on March 17, 2021. 
contributions to the field of Neurology in Brazil, as well as to highlight his non-medical related activities.

\section{MEDICINE AND NEUROLOGY}

Faustino Monteiro Esposel (1888-1931) was born in the city of Rio de Janeiro, and graduated from the Faculty of Medicine of Rio de Janeiro in 1910, when he submitted his thesis entitled "Cerebral Arteriosclerosis"7,8. He was awarded with a trip to Europe, where he had the opportunity to study with renowned neuroscientists, such as Pierre Marie, Joseph Babinski and Jules Dejérine ${ }^{7,8}$. Shortly after, he applied for an assistant physician position at the Hospital Nacional de Alienados, which would later become the first Neurology Institute in Brazil, founded by Professor Deolindo Couto in $1946^{1,3,5,6}$. During his medical career, he was also head of service at Policlínica de Botafogo and adjunct physician at Santa Casa de Misericórdia in Rio de Janeiro. He has also been an outstanding professor while teaching as full professor and assistant at the Nervous Disease Clinic of the School of Medicine of Rio de Janeiro, as substitute professor in the Neurology and Psychiatry Section of the School of Medicine of Rio de Janeiro, as professor of Neurology at the Fluminense School of Medicine, and as substitute professor of Public Medicine at the Teixeira de Freitas School of Law $^{7,8}$. One of Professor Esposel's major contributions to the field of Neurology, jointly made with his mentor, Autregésilo, is the identification of a semiotic sign, described in their article entitled "Le phénomène de Babinski, provoqué par l'excitation de la cuisse" (The Babinski phenomenon provoked by pressure on the thigh), which was published in the famous journal L'Encéphale in $1912^{5,9}$. The semiotic sign was considered a substitute for Babinski sign, in which the extension of the hallux and fan-shaped opening of the toes could be evoked by stimulus, superficial or deep, on the external surface of the thigh of the limb affected by pyramidal syndrome. (Figure 1) $)^{9,10}$ Van Gijn, in his work entitled "The Babinski sign:

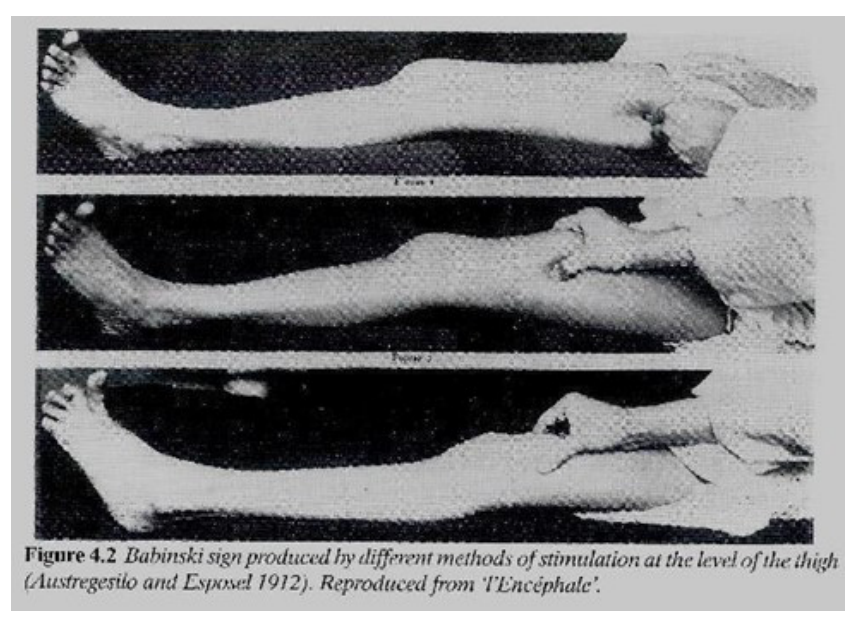

Figure 1. Austregésilo-Esposel sign (1912). (Reproduced from reference 9). a centenary" recognizes the Austregésilo-Esposel sign as a rival $\operatorname{sign}^{11}$. In 1927, Esposel was elected as Full Member of the National Academy of Medicine, holding chair number 58, when he presented a memoir entitled: "Around the Babinski sign"7,8. In 1931, Esposel died as a result of uremia. However, bibliographic data suggest cancer as an underlying disease $\mathrm{e}^{7,8}$.

\section{FOOTBALL CAREER}

In addition to medicine, Esposel was a sports enthusiast, holding various technical and administrative positions in different areas, specially soccer ${ }^{7,8}$. The most relevant position he held was the presidency of Clube de Regatas do Flamengo for three terms: 1920-1922, 1924-1927, 1928-1928, respectively

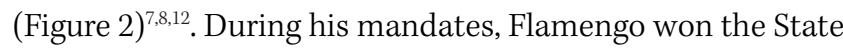
championship five times, in addition to getting from the City Hall a privileged location for the construction of the current club headquarters at Gávea, near the Rodrigo de Freitas Lagoon, in the south area of Rio de Janeiro city ${ }^{7,8,12}$.

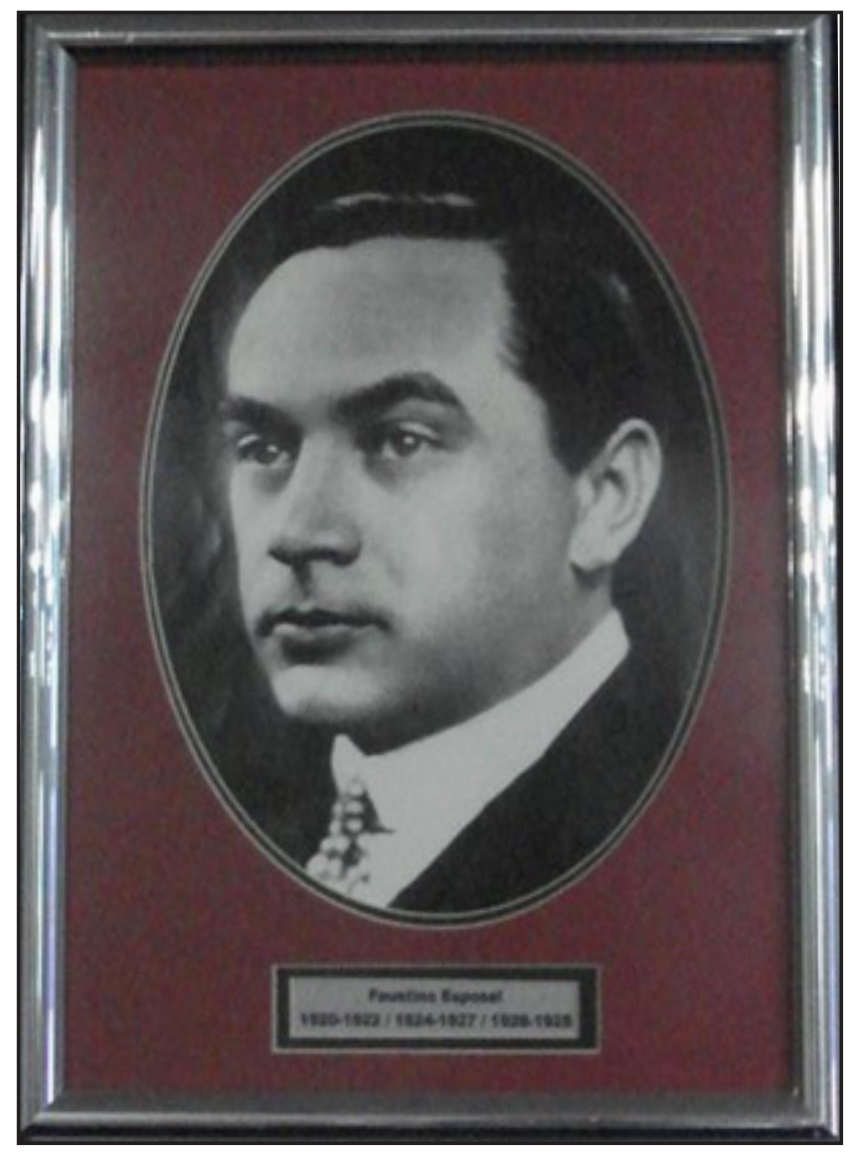

Figure 2. Faustino Esposel (1888-1931) - President of CR Flamengo. (Photograph by Dr. Maria Elisa Paiva Pires).

\section{ESPOSEL'S HISTORY WITH SPIRITUALISM}

A very controversial subject was Esposel's involvement with spiritualism ${ }^{7,8,12}$. Some biographical data suggest that his 
interest in spiritualism arose only after he had been diagnosed with cancer and the final stage of uremia. However, there is information published in the local media suggesting an interest prior to the onset of his disease ${ }^{7,8,12}$. Luciano dos Anjos, a journalist who studies spiritualism, suggests in his work "The True André Luiz" that the identity of the spirit André Luiz would be that of doctor Esposel in life ${ }^{12}$. The relationship of doctors, researchers and intellectuals in general with spiritualism always raises many discussions, in general fierce and without definite conclusions, such as the famous case of doctor and writer Arthur Conan Doyle, among others ${ }^{13,14}$.

\section{CONCLUSION}

Faustino Esposel is considered one of the pioneers of Brazilian Neurology, along with his mentor Antônio Austre- gésilo. Together they described an important semiotic sign, which has been considered a sign rivaling Babinski sign. At the same time, Esposel has also stood out in matters "beyond medicine", mainly in the sports world when he acted as president of Clube de Regatas do Flamengo, and in a controversial situation involving spiritualism, according to some references.

\section{ACKNOWLEDGEMENT}

The authors would like to thank Professor José Luiz Sá Cavalcanti, from Neurology Department of Federal University of Rio de Janeiro, for his contribution to this manuscript.

\section{REFERENCES}

1. Meira AT, Betini BG, Cardoso F, Gomes MDM, Barbosa ER, Prado RCPD, Teive HAG. First stages towards the establishment of Brazilian neurology faculties. Arq Neuro-Psiquiatr. 2019 Dec;77(12):888-95. https://doi.org/10.1590/0004-282×20190147

2. Gomes MM, Cavalcanti JL, Engelhardt E. French school of Neurology in the 19th and first half of the 20th century, and its influence in Brazil. Arq Neuropsiquiatr. 2013 Oct;71(10):818-21. https://doi. org/10.1590/0004-282×20130129

3. Gomes MM, Teive HAG. História da Neurologia brasileira: cinquentenário da Academia Brasileira de Neurologia: centenário da Neurologia brasileira. São Paulo: Academia Brasileira de Neurologia; 2012.

4. Teive HAG, Almeida SM, Arruda WO, Sá DS, Werneck LC. Charcot and Brazil. Arq Neuropsiquiatr. 2001 Jun;59(2):295-9. https://doi. org/10.1590/s0004-282×2001000200032

5. Teive HG, Sá D, Silveira Neto O, Silveira OA, Werneck LC. [Professor Antonio Austregésilo. The pioneer of neurology and of the study of movement disorders in Brazil]. Arq Neuropsiquiatr. 1999 Sep;57(3B):898-902. Portuguese. https://doi.org/10.1590/s0004$282 \times 1999000500030$

6. Gomes MM. Marcos históricos da Neurologia. Rio de Janeiro: Científica Nacional; 2012.

7. Academia Nacional de Medicina [Internet]. Faustino Esposel [cited 2020 December 28]. Available from: https://www.anm.org.br/ faustino-monteiro-esposel/
8. 8. Martins, Ygor. Faustino Monteiro Esposel [Internet]. Médicos que atuaram no Hospital Nacional de Alienados. Biblioteca Virtual em História do Patrimônio Cultural da Saúde. 2018 [cited 2020 December 28]. Available from: http://hpcs.bvsalud.org/vhl/temas/ historia-saberes-psi/medicos/

9. Austregésilo A, Esposel F. Le phénomène de Babinski, provoqué par éxcitation de la cuisse. L'Encéphale. 1912;7:429-36.

10. Kakitani FT, Collares D, Kurozawa AY, Lima PM, Teive HAG. How many Babinski's signs are there? Arq Neuropsiquiatr. 2010;68(4):662-5. https://doi.org/10.1590/s0004-282×2010000400037

11. Van Gijn J, editor. The Babinski sign: a centenary. Utrecht: Universiteit Utrecht, 1996.

12. Anjos, Luciano dos. O verdadeiro André Luiz [Internet]. Espiritualidade e Sociedade. [cited 2020 December 28]. Available from: http://www.espiritualidades.com.br/artigos/a_autores/anjos_ luciano_tit_verdadeiro_andre_luiz-o.htm

13. Rodin AE, Key JD. Arthur Conan Doyle - physician, author and spiritualist: a diversified genius. J Med Biogr. 1994 May;2(2): 98-102. https://doi.org/10.1177/096777209400200208

14. Menegatti-Chequini MC, Loch AA, Leão FC, Peres MFP, Vallada H. Patterns of religiosity and spirituality of psychiatrists in Brazil and the implications for clinical practice: a latent profile analysis. BMC Psychiatry 2020 Nov;20(1):546. https://doi.org/10.1186/s12888-02002929-x 